\title{
A prolonged ice-age in the late \\ Ediacaran Period: A possible fuse of animal evolution?
}

\author{
RUIMIN WANG ${ }^{1}$, BING SHEN $^{1}$, XIANGUO LANG ${ }^{2}$, BIN \\ WEN $^{3}$, HAORAN MA ${ }^{1}$, YONGBO PENG ${ }^{4}$, RAN HE ${ }^{2}$, \\ CHENQING LI ${ }^{1}$, TIANZHENG HUANG ${ }^{1}$ AND \\ CHUANMING ZHOU ${ }^{5}$ \\ ${ }^{1}$ Peking University \\ ${ }^{2}$ Chengdu University of Technology \\ ${ }^{3}$ University of Geosciences, Wuhan \\ ${ }^{4}$ Nanjing University \\ ${ }^{5}$ Nanjing Institute of Geology and Palaeontology, CAS \\ Presenting Author: 2001110607@pku.edu.cn
}

It is hypothesized that biological evolution in late Ediacaran might be triggered by climate changes, such as the onset of Ediacaran glaciation, which led to the atmosphere oxygenation and ocean oxidation. As the most prominent Ediacaran oxidation event, the Shuram Excursion (SE), records the ocean oxidation and might be triggered by a short-lived Ediacaran glaciation age at $\sim 580 \mathrm{Ma}$. However, there is no direct geological evidence showing the linkage between SE and glaciation, because of no continent containing both $\mathrm{SE}$ and Ediacaran glacial records. Here, we report SE in the Ediacaran Shuiquan Formation that underlies the Hankalchough glacial deposits in Tarim Block, suggesting SE could predate the Ediacaran glaciation. Meanwhile, the direct age constraint on SE and the geochronological data in four sections precisely bracketed SE between $570.2 \pm 1.1 \mathrm{Ma}$ and $562.5 \pm 1.1 \mathrm{Ma}$, supporting the $\mathrm{SE}$ is a primary and synchronous event. Thus, our study indicates the Hankalchough glacial deposit might postdate SE, i.e. after 560 $\mathrm{Ma}$, suggesting the Ediacaran glaciation might have lasted for at least 20 million years. However, the geographic distribution of glacial deposits cannot be resolved by any paleogeographic reconstruction. In order to resolve this contradiction, we speculate the asynchronous glacial records are well explained with an inertial interchange true polar wander (IITPW) i.e., the entire solid Earth rotated $\sim 90^{\circ}$ about the liquid outer core to reinstate inertial alignment with the spin axis from ca.590-575 to $560 \mathrm{Ma}$. The rapid continental movements driven by IITPW can resolve the geographic distributions of Ediacaran glacial deposits in the context of a non-Snowball Earth climatic condition. In addition, our paleomagnetic modelling also shows that the glaciation mainly occurred in the mid-latitude continents, probably due to the high latitude regression during IITPW. Our study suggests that the Ediacaran ice-age might have persisted from $\sim 580 \mathrm{Ma}$ to at least $560 \mathrm{Ma}$, or presumably as late as 540 Ma. Finally, the persistent global cooling since mid-Ediacaran might have allowed sufficient ventilation of deep ocean, triggering the evolution of Ediacara Biota and metazoans. 